\title{
Physicochemical properties of both drinking and domestic waters in Çorum
}

\author{
Emre Bezgin $^{1} \mathbb{D}^{*}$, Cem Ozan $_{\text {Eryücel }}^{2} \mathbb{E}$, Zübeyir Tuncel $^{2}$ \\ ${ }^{1}$ Hitit University, Institute of Science, Department of Chemical Engineering, Çorum/Turkey \\ ${ }^{2}$ Çorum Municipality, Water and Sewerage Directorate, Laboratory and Scada Control \\ Center, Çorum/Turkey
}

\begin{abstract}
Water is the most basic need of life since the existence of living things. Physicochemical monitoring of water quality is important for public health. In this study, we aimed to research the quality of drinking and domestic waters in dams, sources, wells and water tanks, located in Çorum in terms of several physicochemical parameters. In winter, spring and summer seasons we collected a total of 2894 water samples from 3 dams, 10 well-sources, and water tanks on a monthly basis; water tanks in the 80 different locations in the Center six days a week, and lastly domestic waters five days a week in $250 \mathrm{~mL}$ sterile water sampling bottles. We used the nephelometric method for determining the amount of turbidity, the electrometric method for analyzing conductivity, $\mathrm{pH}$ and issolved oxygen the photometric method for measuring free chlorine, the spectrophotometric method for determining the amount of sulphate, iron, nitrite, ammonia and manganese and lastly TS 266 volumetric titration for analyzing total alkalinity, organic matter, magnesium, calcium and total hardness. We monitored water height, filling rate, turbidity, $\mathrm{pH}$ and free chlorine control in each drinking water storage tanks in Çorum with the Scada System and free chlorine with both the Scada System and manually. Detected in the range of Ammonium and Iron $(\mathrm{mg} / \mathrm{L}):<0.5$; Nitrite $(\mathrm{mg} / \mathrm{L})$ : <0.02; Manganese $(\mathrm{mg} / \mathrm{L})$ : <0.01; Turbidity (NTU): between 0.1 and 0.4 ; Conductivity $(\mu \mathrm{S} / \mathrm{cm})$ : between 400 and $600 ; \mathrm{pH}$ : 7.5 to 8.0 ; Sulfate $(\mathrm{mg} / \mathrm{L})$ : 10 to 45 ; Total Alkalinity (mg/L): between 180 and 250; Organic matter (mg/L): 1 to 3. In accordance with Turkish Regulation on Water Intended for Human Consumption, the several physicochemical parameters in drinking and domestic waters in Çorum are in between stated values.
\end{abstract}

Article History

Received 05.07.2019

Accepted 08.08.2019

${ }^{1}$ Correspondence: emreebezgiin@gmail.com 


\section{Introduction}

Although water is the most widely occurring substance on earth, only 2.53 percent is freshwater. Some about two-thirds of this freshwater is locked up in ice-field and consistent snow cover (WWAP 2003). The water quality is of major significance also for human lives as it is frequently consumed (Cieszynska et al., 2012). During the last decades, anthropogenic activities have deteriorated water quality of reservoirs worldwide (Çelekli and Öztürk, 2014).

One of the most prominent environmental challenges of this century is to sustain natural biological constructive and functional propertys of aquatic ecosystems, rivers in specific. This target requires that we know the condition of these active systems and how they are being affected by specific agent and potency (Aazami et al., 2015; Ogren, 2014). Today, we can readily see that there are many contaminants in the environment due to anthropogenic activities. The annihilation of natural habitats and the presence of environmental pollutants may affect the ecological equilibrate of every ecosystem (Begon et al., 2009; Aazami et al., 2015).

Evaluation and sorting of ecological water quality using indices-based near can help the preservation and direction of water. The measurement of physicochemical parameters is usually time-consuming, payment-intense and also dependent on exclusive instruments. However, physicochemical parameters can only indicate water quality at the moment of dimension, and these can change over time (Gholizadeh et al., 2016; Engman et al., 1991).

Water quality work is the process of defining the chemical, physical and biological characteristics of water mass and detecting the possible contamination sources that reduce the quality of water (Gholizadeh et al., 2016; Usali and Ismail, 2010). Reduction of the quality of water resources may result from waste emptys, pesticides, heavy metals, aliment microorganisms, and residues. Different water quality standards have been developed to help in inspecting the rate of water pollution, and can a result to protect these quality standards (Gholizadeh et al., 2016).

Necessities for water quality and preservation precaution of drinking water reservoirs: (1) to establish a decision-making model integrating GIS (Geographic Information Systems) and analyzing the probable factors effecting reservoir water quality; (2) to identify the parameters 
that are most nearly concerned to water quality and define the quantitative importance of these factors on water quality; (3) to analyze the correlation between the identified necessary parameters and water quality and ensure basic knowledge for improving the protection of reservoir water resources (Gu et al., 2014).

Volumetric analysis, gravimetric analysis and colorimetric analysis methods are some of the methods used in physicochemical analysis. Volumetric analysis is based on volume measurement. The aim of the gravimetric analysis is to determine the weight of a substance. To be quantitatively analyzed by the colorimetric method, the compound must form certain characteristic colors, and the resulting color intensity must be directly commensurate to the concentration of these substances (Samsunlu, 2013).

There was no comprehensive study in the literature. It is clear that this study, prepared for the detection and prevention of substances which affect the life, will an example to many province and it will fill a significant gap in this area in terms of its application.

The study is first and original regarding the evaluation of physicochemical parameters of Çorum. In this study, we aimed to investigate some quality of physical chemistry of the dam, sources-well, tank and drinking water used in the center of Çorum. Furthermore, all the newly established Scada systems for drinking water used for consumption in the Çorum Province was controlled and supervised.

\section{Materials and Methods}

In Çorum province (center) water samples from three dams, ten sources-wells, and water tanks on a monthly basis; water tanks in the 80 different locations in the center six days a week, and lastly domestic waters five days a week were taken in compliance with the hygiene rules in $250 \mathrm{~mL}$ individual sterile drinking water bottles. In winter, spring and summer seasons, 2894 samples taken from dams, sources-wells, water tanks, and tap water in the region were used as the material (Table 1). The parameters analyzed physicochemically; Turbidity, pH, Conductivity, Dissolved Oxygen, Free Chlorine, Iron, Manganese, Ammonium, Nitrite, Sulfate, Total Hardness, Calcium, Magnesium, Organic matter, Total Alkalinity, Bicarbonate, Carbonate, Hydroxide. The methods used are; for Turbidity: Nephelometry Method (Turbiquant 3000 IR), for Dissolved Oxygen, pH and Conductivity: 
Electrometric Method (Inolab Multi 9430), for Free Chlorine: Photometric Method (Lovibond MD100), for Sulphate, Iron, Manganese, Ammonia and Nitrite: Spectrophotometric Method (Prove 600), for Total Alkalinity, Total Hardness, Calcium, Magnesium, Organic Matter: TS 266 Volumetric Titration (Table 2). In Çorum, water used for consumption supervised which has the height of all the storage of drinking water, fill rate, turbidity, $\mathrm{pH}$, free chlorine control with Scada system; furthermore, free chlorine is supervised both Scada system and manually.

Monthly controlled dams, sources, wells, stations and tank; Hatap (dam), Yenihayat (dam), Çomar (dam); Pınarbaşı (well), Pınarbaşı (sources), Konaklı (well), Sağmaca (sources), Elmalı (sources), Kavacık (sources), Mürsel (sources), Ayarık (well), Eskice (station), Sıklık (tank). Five different endpoints for each tank where daily routine control is performed; There are 40 different localities belonging to Akkent, Ayarık, Bağcılar, Bahabey, Çamlık, Kale, Melikgazi and Nadik tanks (Figure 1-3). Images from all locations are created using the Google Earth Pro program. Coordinates of endpoints of all tanks can be obtained from the $1^{\text {st }}$ register if requested (Table 3 ).

Table 1. The total number of analyzes between january and july

\begin{tabular}{ccccccccc}
\hline Water Sources & January & February & March & April & May & June & July & Total \\
\hline Endpoints & 3344 & 3040 & 3496 & 3040 & 3192 & 3040 & 3192 & 22344 \\
\hline Tank & 3952 & 3648 & 4104 & 3800 & 3952 & 3648 & 3952 & 27056 \\
\hline Public Health & 304 & 228 & 304 & 247 & 399 & 247 & 323 & 2052 \\
\hline $\begin{array}{c}\text { Sources- } \\
\text { Wells }\end{array}$ & 152 & 152 & 171 & 190 & 190 & 190 & 171 & 1216 \\
\hline Hatap Dam & - & - & - & 418 & 437 & - & 437 & 1292 \\
\hline $\begin{array}{l}\text { Yenihayat } \\
\text { Dam }\end{array}$ & - & - & - & 304 & 247 & - & 190 & 741 \\
\hline Çomar Dam & - & - & - & - & 247 & - & 190 & 437 \\
\hline Total & 7752 & 7068 & 8075 & 7999 & 8664 & 7125 & 8455 & 55138 \\
\hline
\end{tabular}


Table 2. Physicochemical parameters for drinking and usage waters based on the "Turkish regulation on water intended for human consumption"

\begin{tabular}{lll} 
Parameter & Parametric Value & Unit \\
\hline Ammonium & 0.5 & $\mathrm{mg} / \mathrm{L}$ \\
Nitrite & 0.5 & $\mathrm{mg} / \mathrm{L}$ \\
Turbidity & 1 & $\mathrm{NTU}$ \\
Conductivity & 2500 & $\mu \mathrm{S} / \mathrm{cm}$ \\
$\mathrm{pH}$ & $\geq 6.5 \mathrm{pH} \leq 9.5$ & $\mathrm{pH} \mathrm{Units}$ \\
Iron & 0.2 & $\mathrm{mg} / \mathrm{L}$ \\
Manganese & 0.05 & $\mathrm{mg} / \mathrm{L}$ \\
Free Chlorine & $0.1-0.5$ & $\mathrm{mg} / \mathrm{L}$ \\
Temperature & - & ${ }^{\circ} \mathrm{C}$ \\
Sulfate & 250 & $\mathrm{mg} / \mathrm{L}$ \\
Dissolved Oxygen & - & $\mathrm{mg} / \mathrm{L}$ \\
Calcium & 200 & $\mathrm{mg} / \mathrm{L}$ \\
Magnesium & - & $\mathrm{mg} / \mathrm{L}$ \\
Total Hardness $\left(\mathrm{CaCO}_{3} / \mathrm{L}\right)$ & - & $\mathrm{mg} / \mathrm{L}$ \\
Organic Matter & - & $\mathrm{mg} / \mathrm{L}$ \\
Total Alkalinity $\left(\mathrm{CaCO}_{3}\right)$ & - & $\mathrm{mg} / \mathrm{L}$ \\
Bicarbonate & - & $\mathrm{mg} / \mathrm{L}$ \\
Carbonate & - & $\mathrm{mg} / \mathrm{L}$ \\
Hydroxide & - & $\mathrm{mg} / \mathrm{L}$ \\
\hline
\end{tabular}

Table 3. Latitude and longitude of dams, source-wells and tanks

\begin{tabular}{lll}
\hline Dams, Sources-Wells and Tanks & Latitude & Longitude \\
\hline Hatap dam & 40.371560 & 34.802000 \\
Yenihayat dam & 40.393064 & 34.666789 \\
Çomar dam & 40.580818 & 34.988632 \\
Pınarbaşı well & 40.680239 & 35.289949 \\
Pinarbaşı source & 40.677296 & 35.314425 \\
Konaklı well & 40.631342 & 35.236364 \\
Sağmaca source & 40.593427 & 35.131958 \\
Elmalı source & 40.520783 & 35.027552 \\
Kavacık source & 40.553970 & 35.057642 \\
Mürsel source & 40.557053 & 35.005191 \\
Ayarık well & 40.594646 & 34.982869 \\
Eskice station & 40.612227 & 35.147155 \\
Siklık tank & 40.592923 & 35.048109 \\
Ayarık tank & 40.586426 & 34.982597 \\
Çamlık tank & 40.556197 & 34.975061 \\
Bahabey tank & 40.556629 & 34.974697 \\
Akkent tank & 40.530988 & 34.890307 \\
Nadık tank & 40.552773 & 34.987481 \\
Kale tank & 40.531153 & 34.978864 \\
Bağcılar tank & 40.522415 & 34.955798 \\
Melikgazi tank & 40.559610 & 35.000202 \\
\hline
\end{tabular}




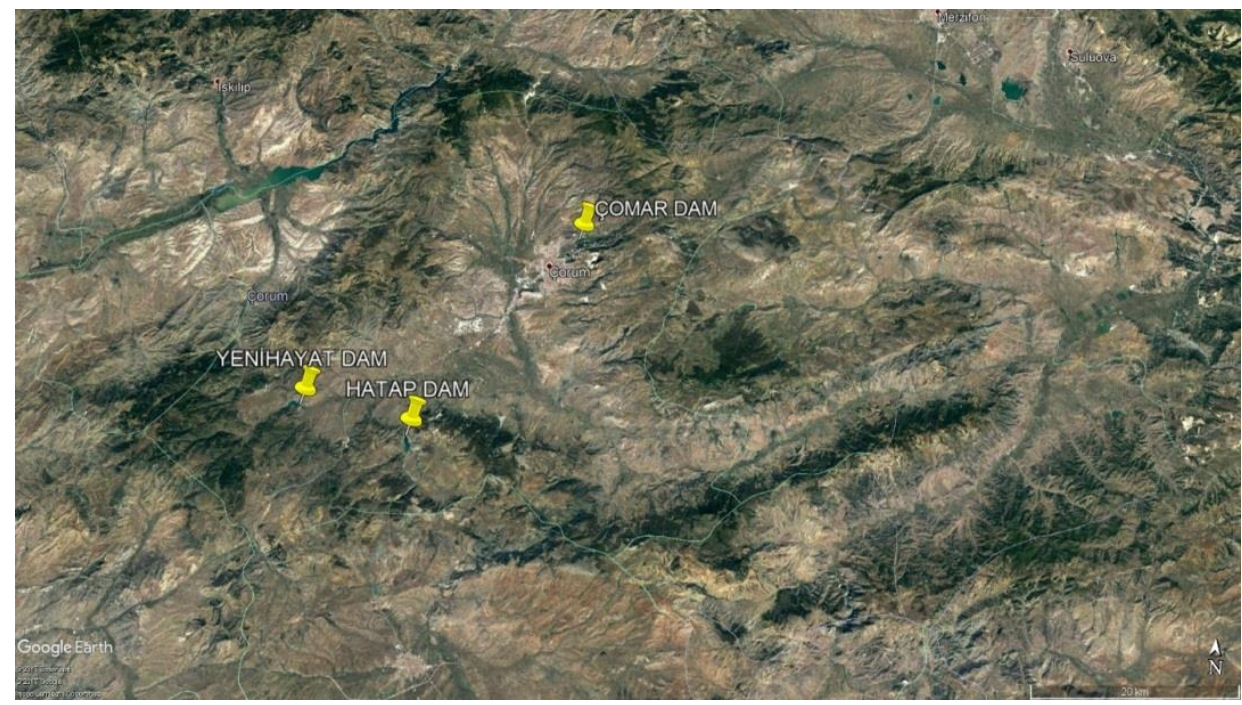

Figure 1. Dams in Çorum that were controlled monthly.

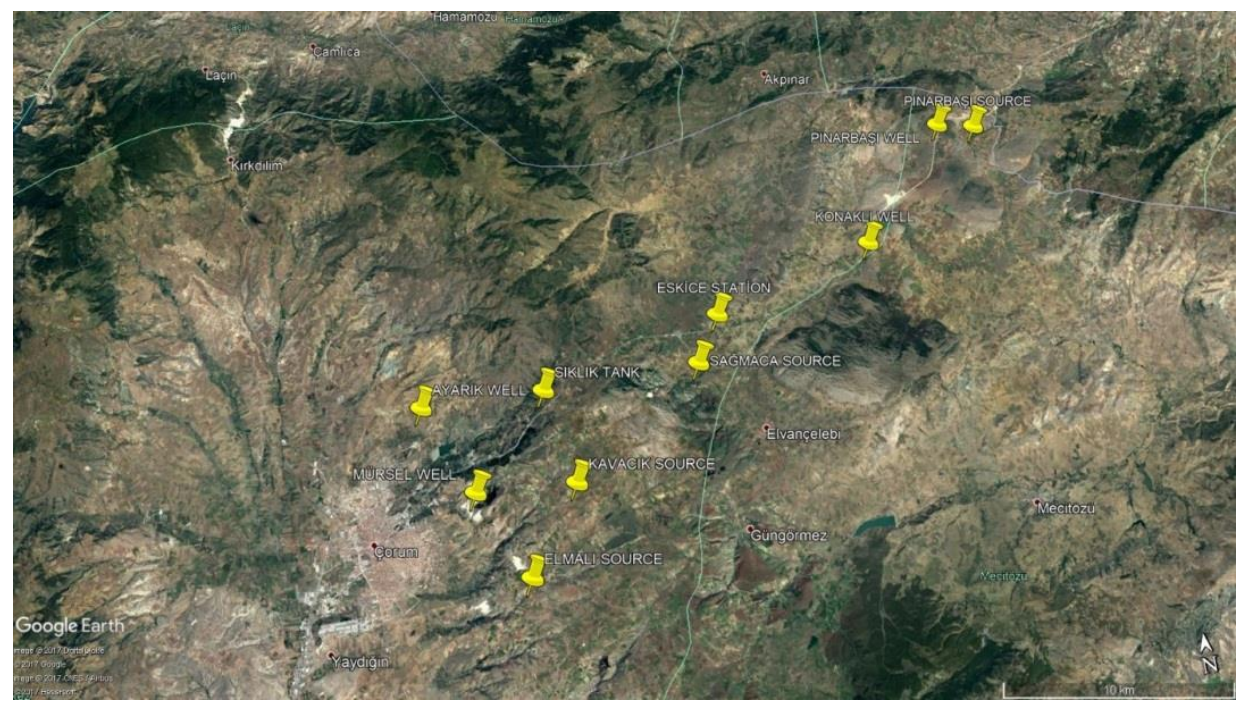

Figure 2.Sources, wells, station and tank facilities in Çorum that were controlled monthly.

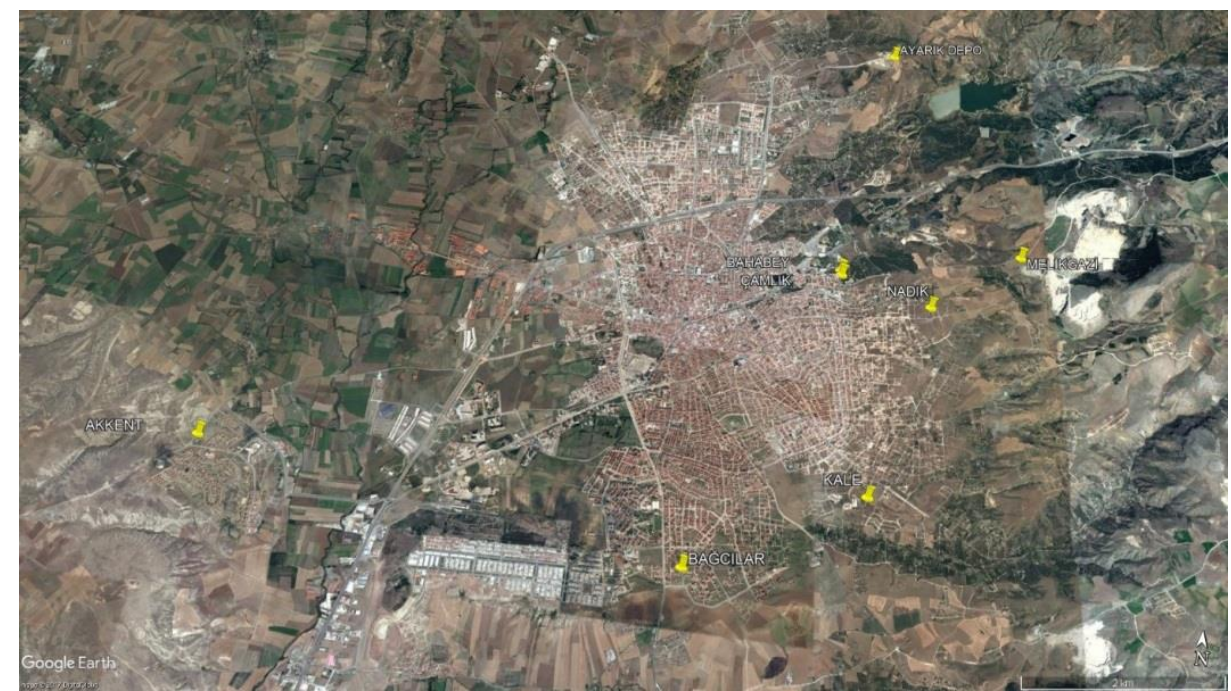

Figure 3. Tanks in Çorum that were controlled daily. 
Measurement of turbidity was carried out by nephometric (light scattering by the particle) method. When measuring, $20-25 \mathrm{~mL}$ of the water sample was taken into the reaction vessel, the sample was placed in the device, and the device performed automatic reading.

$\mathrm{pH}$, conductivity, dissolved oxygen, temperature measurement was done by electrometric (method based on measuring an electrical property such as voltage current and conductivity) method. $250 \mathrm{~mL}$ of the water sample was taken, the measuring probe was placed on the example made, and the device was automatically read.

Free clorine was measured photometrically (quantitation method based on measurement of light intensity in a specific spectrum). The reaction vessel containing $10 \mathrm{~mL}$ of purified water was zeroed in the device, and then $10 \mathrm{~mL}$ of the water sample was read in the machine.

Spectrophotometric method (quantitative determination method based on absorption of some colors of light spectrum of light colored material placed between light source and prism and showing weak or strong band in the spectrum according to concentration) was used in the measurement of ammonium, nitrite, iron, manganese, and sulphate.

When making ammonium, $5 \mathrm{~mL}$ of sample was placed in the reaction bath and mixed, then $0.6 \mathrm{~mL}$ of $\mathrm{NH}_{4}-1$ were added and stirred, then 1 level micro spoon $\mathrm{NH}_{4}-2$ was added and mixed. It was waited 5 minutes. Four drops of $\mathrm{NH}_{4}-3$ were added dropwise and stirred, again waiting for 5 minutes. The method was selected by placing the AutoSelector in the tub holder. Finally, the bathtub wassetin the recess, and automatic reading take was place.

When making nitrite; was put $5 \mathrm{~mL}$ of sample in a test tube, add one blue micro spoon $\mathrm{NO}_{2}-1$, mixed to reagent dissolve. The reaction time was 10 minutes. The solution was transferred to the appropriate ampoule. The method was selected by placing the AutoSelector in the tub holder. Automatic reading was done by placing it in the bathtub socket.

When making iron; was put $5 \mathrm{~mL}$ of sample in a test tube, add three drops of Fe-1. Reaction time was 3 minutes. The solution was transferred to the appropriate ampoule. The method was selected by placing the AutoSelector in the tub holder. Automatic reading was done by puttingit in the bathtub socket. 
When making manganese; was put $10 \mathrm{~mL}$ of sample in a test tube, add eight drops of Mn-1 and then add two drops of $\mathrm{Mn}-2$. The reaction time was 2 minutes. Four drops of $\mathrm{Mn}-3$ are added and mixed. The reaction time was 2 minutes. The solution was transferred to the appropriate ampoule. The method was selected by placing the AutoSelector in the tub holder. Automatic reading was done by placing it in the bathtub socket.

When making the sulphate; was pipet into the $0.5 \mathrm{~mL} \mathrm{SO}_{4}-1$ test tube. $5 \mathrm{~mL}$ of sample was added to the pipette and mixed. One blue micro spoon $\mathrm{SO}_{4}-2$ was added. The reagent was stirred until the tube was dissolved. The reaction time was 2 minutes. The solution was transferred to the appropriate ampoule. The method was selected by putting the AutoSelector in the tub holder. Automatic reading was done by placing it in the bathtub socket.

The TS-266 wet method was used for determination of the organic matter. In the decision of the organic substance, $50 \mathrm{~mL}$ of the water sample was added to $100 \mathrm{~mL}$ of Erlenmeyer flask. $5 \mathrm{~mL}$ of dilute $\mathrm{H}_{2} \mathrm{SO}_{4}$ and $5 \mathrm{~mL}$ of $\mathrm{KMnO}_{4}$ were added. The water bath was kept at $90^{\circ} \mathrm{C}$ for 30 minutes. The remaining color of the potassium permanganate was then removed by adding $5 \mathrm{~mL}$ of ammonium oxalate solution. If the color is white, it is titrated back to 0.01 N Potassium Permanganate until a slightly pink color appears on the sample. Two times the amount of Potassium Permanganate consumed gives the result of organic matter.

The TS-266 wet method was used for determination of hardness. Determination of hardness substance; C Consumption; $25 \mathrm{~mL}$ of water was added to $25 \mathrm{~mL}$ of purified water. Added $1 \mathrm{~mL}$ of Hydroxylamine Hydrochloride solution and $1 \mathrm{~mL}$ of Ammonium Chloride solution. Then add KromBlack T with the spatula tip. It was titrated with standard EDTA. The color was made gradually from reddish pink to blue.

A consumption; $25 \mathrm{~mL}$ of a suitable sample was taken, and $25 \mathrm{~mL}$ of purified water was added. $1 \mathrm{~mL}$ of Hydroxylamine Hydrochloride and $1 \mathrm{~mL}$ of Sodium Hydroxide were added to $1 \mathrm{~mL}$ of Sodium Cyanide. Added Calcium indicator with a spatula and titrate with standard EDTA. This process continues until the color changes from yellowish pink to orchid purple.

The TS-266 wet method was used for determination of alkalinity. 
Phenolphthalein alkanity: Sample was taken from $50 \mathrm{~mL}$ sample. The $\mathrm{pH}$ meter was immersed in the stirred beaker in the magnetic stirrer. If the measured $\mathrm{pH}$ balance is higher than 8.3, 5-6 drops of phenolphthalein are instilled. $0.02 \mathrm{~N} \mathrm{H}_{2} \mathrm{SO}_{4}$ and $\mathrm{pH}$ 8.3. The volume of titrant used was noted $(\mathrm{Vp})$.

$$
\mathrm{P}=20 \mathrm{x} \mathrm{Vp}
$$

Total alkalinity: The same solution was instilled with $0.5 \mathrm{~mL}$ of methyl iodide. Take an orange color at $\mathrm{pH} 4.5$ with $0.02 \mathrm{~N} \mathrm{H}_{2} \mathrm{SO}_{4}$. The volume of titrant used was noted. ( Vm)

If the initially measured $\mathrm{pH}$ is $<8,3$, titration is performed by adding a methyl oranj indicator.

$$
\mathrm{T}=(\mathrm{Vp}+\mathrm{Vm}) \times 20(\text { Table } 4)
$$

Table 4. Volumetric analysis of some chemical parameters

\begin{tabular}{llll}
\hline Titration & Carbonate Alkalinity & Bicarbonate Alkalinity & Hydroxide Alkalinity \\
\hline $\mathrm{Vp}=\mathrm{Vm}$ & $2 \mathrm{p}$ & 0 & 0 \\
$\mathrm{Vp}=0$ & 0 & $\mathrm{~T}$ & 0 \\
$\mathrm{Vm}=0$ & 0 & 0 & $\mathrm{P}$ \\
$\mathrm{Vm}>\mathrm{Vp}$ & $2 \mathrm{p}$ & $\mathrm{T}-2 \mathrm{P}$ & 0 \\
$\mathrm{Vm}<\mathrm{Vp}$ & $2(\mathrm{~T}-\mathrm{P})$ & 0 & $2 \mathrm{P}-\mathrm{T}$ \\
\hline
\end{tabular}

Water coming from Sağmaca (source), Konaklı (well), Pınarbaşı (well) and Pınarbaşı (source) is transferred to Eskice station; Water coming from Elmalı and Kavacik sources is transferred to Kale tank; The water coming from the Mürsel and Eskice stations is transferred to the Melikgazi tank, and also the water coming from the Eskice stations is transferred to the Ayark tank and supplied to the network by chlorination. The water from Akkent, Bağcilar, Bahabey, Çamlık and Nadık tank is collected from Çomar, Hatap and Yenihayat Dams, which are treated and transferred from Treatment Plant in Çorum.

\section{Results and Discussion}

According to Turkish Regulation on Water Intended for Human Consumption; the results of the physicochemical parameter analysis of 2700 water samples taken from tanks and water faucetsbetween January and July in Çorum city center as a result of daily control and inspection, it was determined chlorine valuein the range of $0.2-0.5 \mathrm{mg} / \mathrm{L}$. Detected in the range of Ammonium and Iron (mg/L): <0.5; Nitrite (mg/L): <0.02; Manganese (mg/L): <0.01; Turbidity (NTU): between 0.1 and 0.4 ; Conductivity $(\mu \mathrm{S} / \mathrm{cm}$ ): between 400 and 600; $\mathrm{pH}: 7.5$ 
to 8.0; Sulfate (mg/L): 10 to 45; Total Alkalinity (mg/L): between 180 and 250; Organic matter (mg/L): 1 to 3 .

Temperature, dissolved oxygen, and total hardness values do not have an average parametric value specified in the regulation. According to the seasonal variation of sample results of the tank and endpoints physicochemical parameter analysis; Temperature value $\left({ }^{\circ} \mathrm{C}\right)$ : Detected in the range of 9 to 25, Dissolved Oxygen value: 10 to 7.5 and Total Hardness value: 190 to 270 .

The analysis results of 108 tap water samples taken routinely in accordance with the program determined together with the environmental health teams of the Çorum provincial health directorate are shared.

Increase in turbidity, conductivity, dissolved oxygen, iron, manganese, ammonia, nitrite, sulfate, total hardness, organic matter, total alkalinity rate depending on the depth and seasonal variation in the total of 194 water samples taken from the dams, sources, and wells used for consumption in Çorum have been identified

Water hardness can occur in different shapes in each region. It is related to the geological structure of the location where water hardness of the Çorum province is located. Groundwater is known to be harder than surface waters. The total hardness of the analyzed welds and wells was higher than the total hardness of the dams. Research shows that; hard water does not make any impact on human health and does not cause health problems.

Variation in organic matter comes into play due to the circulation period in the water in sources. Anaerobic conditions occur because of the increase in the organic basement of the organic matter and the inability of the water and air to come into contact. When the organic matter is broken down, the formation of $\mathrm{CO}_{2}$ in the bottom zone is observed. Thus, a decrease in the amount of dissolved oxygen is detected.

The physicochemical data of dams and all sources-wells were given in the following tables (Table 5-8). 
Table 5. Physicochemical values of Çomar dam

\begin{tabular}{|c|c|}
\hline Çomar Dam & $\begin{array}{l}\text { According to the results of the analysis carried out 1-13 meter } \\
\text { range in May and July }\end{array}$ \\
\hline Ammonia and Iron: & less than $0.05 \mathrm{mg} / \mathrm{L}$, showing only an increase in the 13 th meter \\
\hline Nitrite value: & less than $0.02 \mathrm{mg} / \mathrm{L}$ \\
\hline Manganese value: & increased from 0.3 to $1.3 \mathrm{mg} / \mathrm{L}$, only at the 13 th meter \\
\hline Conductivity value: & 500 to $600 \mu \mathrm{S} / \mathrm{cm}$ \\
\hline pH value: & between 7.4 and 8.8 in May; It varied from 8.3 to 9 in July \\
\hline Sulphate value: & $\begin{array}{l}\text { between } 74 \text { and } 105 \mathrm{mg} / \mathrm{L} \text {, the highest value was found at the } 13 \text { th } \\
\text { meter }\end{array}$ \\
\hline Organic matter value: & 4 to $12 \mathrm{mg} / \mathrm{L}$ in May; It varied from 4 to $4.8 \mathrm{mg} / \mathrm{L}$ in July. \\
\hline Turbidity value: & $\begin{array}{l}\text { varied from } 3.5 \text { to } 10 \text { NTU. Although this value cannot depend on } \\
\text { the depth, it differs only from the water sample at the 13th meter taken } \\
\text { from the dip }\end{array}$ \\
\hline Temperature readings: & $\begin{array}{l}9 \text { to } 16^{\circ} \mathrm{C} \text { in May; seasonally varying between } 14 \text { and } 23^{\circ} \mathrm{C} \text { in July. } \\
\text { Also, the temperature decreased with increasing depth in the water } \\
\text { samples taken from the bottom }\end{array}$ \\
\hline Dissolved Oxygen level: & $\begin{array}{l}\text { varied between } 4 \text { and } 10 \mathrm{mg} / \mathrm{L} \text { in May and between } 0.6 \text { and } 8 \mathrm{mg} / \mathrm{L} \\
\text { in July. This variation showed a decrease in the amount of dissolved } \\
\text { oxygen in the water samples taken from the bottom depending on the } \\
\text { range of } 1-13 \text { meters }\end{array}$ \\
\hline Total Hardness value: & around $230 \mathrm{mg} / \mathrm{L}$. \\
\hline
\end{tabular}

Table 6. Physicochemical values of Hatap dam

\begin{tabular}{|c|c|}
\hline Hatap Dam & $\begin{array}{l}\text { According to the results of the analysis carried out 1-23 meters } \\
\text { in April, May, and July }\end{array}$ \\
\hline Ammonium and Iron: & less than $0.05 \mathrm{mg} / \mathrm{L}$, only increased by 23 meters \\
\hline Nitrite value: & less than $0.02 \mathrm{mg} / \mathrm{L}$, showing an increase only at the $23 \mathrm{rd}$ meter \\
\hline Manganese value: & increased between 0.01 and $0.7 \mathrm{mg} / \mathrm{L}$, only at the $23 \mathrm{rd}$ meter \\
\hline Conductivity value: & Detected at between 468 and $560 \mu \mathrm{S} / \mathrm{cm}$ \\
\hline pH value: & $\begin{array}{l}\text { in the range of } 7.2 \text { to } 8.6 \text { in April and May; It varied from } 7.2 \text { to } 8.9 \\
\text { in July }\end{array}$ \\
\hline Sulfate value: & $\begin{array}{l}\text { between } 28 \text { and } 63 \mathrm{mg} / \mathrm{L} \text {, the highest amount was found at the } 23 \mathrm{rd} \\
\text { meter }\end{array}$ \\
\hline Organic matter value: & between 2.4 and 5.6 mg/L in April, May, and July \\
\hline Turbidity value: & $\begin{array}{l}\text { between } 1 \text { and } 57 \text { NTU. Although this value cannot depend on the } \\
\text { depth, it differs only in the water sample taken at the 23rd meter taken } \\
\text { from the dip in July }\end{array}$ \\
\hline Temperature values: & $\begin{array}{l}6 \text { to } 16^{\circ} \mathrm{C} \text { in April and May; seasonally varying between } 6 \text { and } 25 \\
{ }^{\circ} \mathrm{C} \text { in July. Also, the temperature decreased with increasing depth in the } \\
\text { water samples taken from the bottom }\end{array}$ \\
\hline Dissolved Oxygen level: & $\begin{array}{l}\text { varied from } 0.1 \text { to } 10 \mathrm{mg} / \mathrm{L} \text { in April, May, and July. This variability } \\
\text { showed a decrease in the amount of dissolved oxygen in the water } \\
\text { samples taken from the bottom depending on the range of } 1-23 \text { meters }\end{array}$ \\
\hline Total Hardness value: & around 200 to $250 \mathrm{mg} / \mathrm{L}$ \\
\hline
\end{tabular}

Table 7. Physicochemical values of Yenihayat dam

\begin{tabular}{ll}
\hline Yenihayat Dam & $\begin{array}{c}\text { According to the results of the analysis carried out 1-16 meter } \\
\text { range in April, May, and July }\end{array}$ \\
\hline Ammonium and Iron: & between 0.05 and $1.5 \mathrm{mg} / \mathrm{L}$ in April and May, only at the $13 \mathrm{th}$ \\
meter; Increased by only $10 \mathrm{~meters}$ in the range of 0.4 to $1.5 \mathrm{mg} / \mathrm{L}$ in \\
July \\
increased from $0.02 \mathrm{mg} / \mathrm{L}$ to $0.1 \mathrm{mg} / \mathrm{L}$ in July, while it was 0.02 \\
No/trite value: & $\begin{array}{l}\text { in April and May } \\
\text { between } 0.05 \text { and } 1.4 \mathrm{mg} / \mathrm{L} \text { in April and May, only at the } 13 \mathrm{th} \\
\text { meter; In July, it increased from } 0.03 \text { to } 0.9 \mathrm{mg} / \mathrm{L} \text {, only by the } 10 \text { th }\end{array}$ \\
Manganese value: &
\end{tabular}


Conductivity value:

$\mathrm{pH}$ value

Sulphate value:

Organic matter value:

Turbidity value:

Temperature value:

Dissolved Oxygen level:

Total Hardness value: meter July

610 to $670 \mu \mathrm{S} / \mathrm{cm}$ in April and May, and 580 to $640 \mu \mathrm{S} / \mathrm{cm}$ in

in the range of 8.2 to 8.8 in April and May; It varied from 8 to 9 in July. This variability was detected as a decrease in $\mathrm{pH}$ at the 10th month in July and at the 13th meter in April and May in water samples taken from the bottom

between 18 and $118 \mathrm{mg} / \mathrm{L}$, the highest value was found at the 13th meter in April and May

between 3.2 and $4.8 \mathrm{mg} / \mathrm{L}$ in April, May, and July. This increased only 10th meters in July and 13th meters in April and May, depending on depth in the water samples taken from the dip

between 4.3 and $30 \mathrm{NTU}$ in April and May; It is in the range of 2.4 to 16 NTU in July. This increased only 10 meters in July and 13 meters in April and May, depending on depth in the water samples taken from the dip

9 to $16{ }^{\circ} \mathrm{C}$ in April and May; seasonally varying between 10 and $22{ }^{\circ} \mathrm{C}$ in July. Also, the temperature decreased with increasing depth in the water samples taken from the bottom

between 0.2 and $8 \mathrm{mg} / \mathrm{L}$ in July and between 2.1 and $8.6 \mathrm{mg} / \mathrm{L}$ in April and May. This variability showed a decrease in the amount of dissolved oxygen in the water samples taken from the bottom depending on the range of 1-23 meters 270 to $280 \mathrm{mg} / \mathrm{L}$

Table 8. Physicochemical values of sources and wells

\begin{tabular}{|c|c|}
\hline Sources and wells & According to the analysis made during January-July \\
\hline Ammonium and Iron: & less than $0.05 \mathrm{mg} / \mathrm{L}$ \\
\hline Nitrite value: & less than $0.02 \mathrm{mg} / \mathrm{L}$ \\
\hline Manganese value: & less than $0,01 \mathrm{mg} / \mathrm{L}$ \\
\hline Conductivity value: & between 412 to $680 \mu \mathrm{S} / \mathrm{cm}$ \\
\hline pH value: & between 6.5 and 8.63 (the highest value was found with the \\
\hline & Elmalı source while the lowest value was found in the Mürsel well) \\
\hline Sulphate value: & $\begin{array}{l}\text { between } 7 \text { and } 44 \mathrm{mg} / \mathrm{L} \text { (the lowest value Sağmaca source while } \\
\text { the highest value was Ayarık well) }\end{array}$ \\
\hline Organic Matter Value: & $\begin{array}{l}\min : 1 \text { to max: } 3.7 \mathrm{mg} / \mathrm{L} \text { (while the highest value was the Elmalı } \\
\text { source, the lowest value was seen in Pinarbaşı source and Pınarbaş1 } \\
\text { well) }\end{array}$ \\
\hline Turbidity value: & $\begin{array}{l}\text { between } 0.07 \text { and } 1.21 \mathrm{mg} / \mathrm{L} \text { (the highest value was the Konakl1 } \\
\text { well while the lowest value was found in the Mürsel well) }\end{array}$ \\
\hline Temperature values: & $\min : 12$ and $\max : 23{ }^{\circ} \mathrm{C}$ \\
\hline Dissolved Oxygen value: & $\begin{array}{l}\text { between } 5.45 \text { and } 9.4 \mathrm{mg} / \mathrm{L} \text { (while the highest value was } \\
\text { Kavacik source, the lowest value was Ayark well) }\end{array}$ \\
\hline Total Hardness value & $\begin{array}{l}\text { around } 270 \text { to } 280 \mathrm{mg} / \mathrm{L} \text { (the highest value is the Kavacik } \\
\text { source while the lowest value is the Mürsel well) }\end{array}$ \\
\hline
\end{tabular}

According to the Regulation on Waters for Human Consumption; because of daily control and inspection, 2894 water sample taken from reservoir outlet and faucet water in Çorum province center did not show any adverse effect on physicochemical parameters 


\section{Conclusion}

All physicochemical properties were measure data the Laboratory and Scada Center of Çorum Municipality Water, and Sewerage Directorate, newly established in January of 2017 and the reported data are unique and new. Physicochemical studies, carried out in large cities of Turkey for years, have been started in Çorum province with this study. It is a very important step for obtaining qualified drinking and domestic water in Çorum province. As Çorum Municipality Laboratory and Scada Center unit, it is aimed to make better water quality and control by adding new analysis.

In line with these targets, the physicochemical parameters (anion and cation determination) of the dams, sources, wells and central tanks and drinking water used in Çorum will continue to be investigated by using chromatographic methods for more accurate analysis of water quality qualities (Table 9).

Table 9. Physicochemical parameters to be measured in the water resources in Çorum

\begin{tabular}{lll}
\hline Parameter & Parametric Value & Unit \\
\hline Fluoride & 1.5 & $\mathrm{mg} / \mathrm{L}$ \\
Chloride & 250 & $\mathrm{mg} / \mathrm{L}$ \\
Nitrate & 50 & $\mathrm{mg} / \mathrm{L}$ \\
Bromate & 10 & $\mu \mathrm{g} / \mathrm{L}$ \\
Potassium & $10-12$ & $\mathrm{mg} / \mathrm{L}$ \\
Sodium & 200 & $\mathrm{mg} / \mathrm{L}$ \\
Lithium & - & $\mathrm{mg} / \mathrm{L}$ \\
\hline
\end{tabular}

In many researches it is clearly seen that in scientific qualification data and methods are inadequate. It is expected that the method information and data transferred in this study will form the basis for the research groups that will work in this area in the future. It is thought that this work will serve as an example and helpful the water control in many municipalities.

\section{Acknowledgements}

We thank Prof. Dr. Ahmet SAMSUNLU (Istanbul Technical University, Faculty of Civil Engineering, Department of Environmental Engineering, Istanbul, Turkey) for his valuable contributions to this study. 


\section{References}

Aazami, J., Esmaili-Sari, A., Abdoli, A., Sohrabi H., Van den Brink, P. 2015. Monitoring and assessment of water health quality in the Tajan River, Iran using physicochemical, fish and macroinvertebrates indices, Journal of Environmental Health Science \& Engineering, 13:29.

Begon, M., Townsend, C.R., Harper, J.L. 2009. Ecology: from individuals to ecosystems, London, UK: Blackwell Publishing.

Cieszynska M., Wesolowski, M., Bartoszewicz, M., Michalska, M., Nowacki, J. 2012. The application of physicochemical data for water-quality assessment of watercourses in the Gdansk Municipality (South Baltic coast). Environmental Monitoring and Assessment, 184(4), 2017-29.

Çelekli, A., Öztürk, B. 2014. Determination of ecological status and ecological preferences of phytoplankton using the multivariate approach in a Mediterranean reservoir. Hydrobiologia, 740,115-135.

Engman, E.T., Gurney, R.J. 1991. Remote sensing in hydrology; Chapman and Hall Ltd. London, UK.

Gholizadeh, M.H., Melesse, A.M., Reddi, L. 2016. A comprehensive review of water quality parameters estimation using remote sensing techniques, Sensors, 16 (1298).

Gu, Q., Deng, Ke Wang, J., Lin, Y., Li, J., Gan, M., Ma, L., Hong, Y. 2014. Identification and assessment of potential water quality impact factors for drinking-water reservoirs, International Journal of Environmental Research and Public Health, 11, 6069-6084.

Ogren, S.A. 2014. Using indicators of biotic integrity for assessment of stream condition, Michigan Tech. 7(5):10-9.

Samsunlu, A. 2013. Environmental engineering chemistry, Birsen Publications, İstanbul, pp398.

TS 266, Water intended for human consumption, Institute of Turkısh Standards, Ankara. 2005.

Usali, N., Ismail, M.H. 2010. Use of remote sensing and gis in monitoring water quality, Journal of Sustainable Development, 3, 228-238.

Water for People Water for Life 2003 The United Nations world water development report. http://unesdoc.unesco.org/images/0012/001295/129556e.pdf. 